\title{
Introduction of Social Media Learning Tool in Teaching of Microbiology
}

\author{
Singla, N. ${ }^{1}$, Kumar, M.B. ${ }^{1} \&$ Badyal, $D .^{2}$
}

\begin{abstract}
Background: Innovation and interaction are two key components which drives successful impartation of any education. Interaction should be increased 'with students' and 'between students' whenever possible to help develop critical thinking skills and concept clearing. Social media is very active in form of Facebook, Twitter or WhatsApp and all these platforms have been used to enhance student learning, peer interaction and communication.
\end{abstract}

Objective: Since this field was yet to be explored IN OUR SETTING, the present study was planned to introduce asynchronous learning via social media using WhatsApp as a teaching-learning tool.

Method: The present observational study was conducted with second professional undergraduate medical students. Due permission from the institute ethics committee was taken for conducting the study. Students and faculty sensitization was done regarding use of WhatsApp as a teaching-learning tool. The topic to be taught was chosen and a module was prepared for the same. After the implementation of module, student feedback and faculty feedback was taken via a pre-framed peer validated questionnaire.

Results: Students and faculty both accepted and found the method innovative, interesting, stimulating and fun. The platform was found to be effective in clarification of concepts related to subject, selfdirected learning and in promoting better teacher student interaction. Faculty agreed that it is a feasible method of teaching but students had mixed views regarding its implementation as a routine method of teaching. Logistically, students felt better time management needed to be there to implement such online teaching modules for better learning and participation.

Conclusion: Healthcare is a challenging profession and students should be ready to adapt to all the newer technologies coming up whether in education sector, social or professional.

Key words: WhatsApp, Social media, Learning, Teaching, Module

\section{Introduction}

Asynchronous learning is the term used when students learn the same material at different times and locations. It is also known as Location Independent Learning.

${ }^{1}$ Department of Microbiology, Government Medical College Hospital, Chandigarh, India.

${ }^{2}$ Department of Pharmacology, Christian Medical College, Ludhiana, India.

Corresponding Author: Dr Nidhi Singla

Associate Professor, Department of Microbiology

Government Medical College Hospital, Chandigarh, India 160030.

Email: nidhisingla76@gmail.com
In it, students complete their work in their own time. It is opposite to Synchronous learning which occurs when classes occur on set schedules and time frames. Students and instructors are there at the same time since lectures, discussions, and presentations take place at specific hours. Asynchronous learning offers benefits of flexible timings, self-directed pacing and improved efficiency in regard to resources available (Worthington, 2013; Sener, 2010).

Students are usually registered on today's popular social networks like Facebook and WhatsApp and frequently use smartphones to

DOI: http://doi.org/10.4038/seajme.v14i1.188

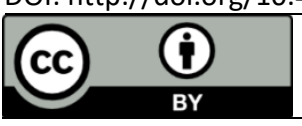

C SEAJME. This is an Open Access article distributed under the terms of the Creative Commons Attribution License (http://creativecommons.org/licenses/by/4.0/), which permits unrestricted use, distribution, and reproduction in any medium, provided the original author and source are credited 
access these sites. With 400 million active users in India, WhatsApp is a messenger application that is very commonly used among all for sending multimedia messages, photos, videos, audios and most commonly, simple text messages (Kustijono \& Zuhri, 2018). Further it has become the most common tool to communicate in the society. Availability of internet facility on mobiles has increased its accessibility and that too without any time constraint. It is freely and widely available. It is easy to join and undergraduate students commonly use it to communicate with each other socially and it has been observed that important messages related to academics are also passed on via WhatsApp by the class representatives to the whole class. At many places, the administrative block dealing with undergraduates especially in private educational settings utilizes this tool to convey important messages related to curricula, attendance or examinations. In recent times, studies have been carried out with students on use of WhatsApp as a teaching-learning tool and four main purposes have been identified: exchange of information, communication, building a social atmosphere and encouraging students to share (Amry, 2015).

WhatsApp can be useful in the learning process as it brings all/ many students and their faculty together at same platform for discussion and clearing of queries to support learning process. Gon \& Rawekar (2017) report that the constant availability of a facilitator and learning anytime anywhere has made WhatsApp a new and convenient tool for teaching-learning activities. Barhoumi (Barhoumi, 2015) did a study on two group of students; one which attended only didactic lectures and other group was where traditional lectures were followed by WhatsApp discussion. The authors concluded that the WhatsApp use in a blended mobile lecture environment was useful as different aspects of same topic can be discussed at length and the tool helps in easily sharing information and knowledge related to the course taught face to face. Similarly, Raiman et al., (2017) used WhatsApp for problem based learning in medical students with clinical attachments and found it to be a feasible and acceptable tool in supplementing Problem Based Learning (PBL) teaching. It can also be an effective tool to increase communication among various clinicians. Alenazi (2018) reports that WhatsApp is a popular application used on a regular basis among college students and can be an effective tool in enhancing pre-service teacher's learning and may be used to assist in the development and implementation of instructional methods to prepare teacher programs that encourage the building of indispensable skills, such as self-regulation skills.

Keeping all this in mind, the present study was planned to introduce social media as a teaching-learning tool using WhatsApp for second professional undergraduate medical students in our setting.

\section{Methods}

The present study was conducted as a prospective observational study in the Department of Microbiology from June 2018 to August 2018. Permission was taken from the Research Committee and Ethics Committee of the Institution to carry out the project.

Step wise methodology is depicted in Figure 1. Students sensitization was done as the first step. Brief interaction was held with the students regarding need to introduce new teaching techniques to hold student interest and enhance their learning. Students were sensitized to the use of WhatsApp as a learning tool. As all of them were already using the application. the task was easy. Explanations were given about how a WhatsApp group will be created with students and the moderators (faculty and residents of the Department of Microbiology). They were informed that only those students who volunteer to be a part of group will be included. Etiquette to be followed while using social media was stressed upon.

The second step was faculty sensitization. Faculty in the department were introduced to the idea and their verbal consent for the same was sought. The possibility for the topic which can be taught via WhatsApp in the subject of Microbiology was discussed and decided upon. 'Laboratory diagnosis of Pyrexia of Unknown Origin' was chosen as per the MBBS class roster at that time.

The topic to be taken was conveyed to the students and a WhatsApp group with the help of the class representative was formed. The module was developed in form of questionnaire to be put up on the WhatsApp group. The questions were carefully chosen to cover the whole topic as well as to introduce the topic systematically to students. The activity was done for a one week period. Every evening after the institution timings, a set of questions were put up to the students on the group. The students were supposed to read the topic on their own and answer those questions on the 
WhatsApp group excerpts from the real conversation are being given (Figure 2). In between, trigger questions or clues to answers were put up, if required, to help them come up with the answers. The whole process of discussion and response between students themselves and with faculty was observed. After one week, the group was dissolved. After the completion of whole process, the didactic lecture on same topic was taken as per roster.

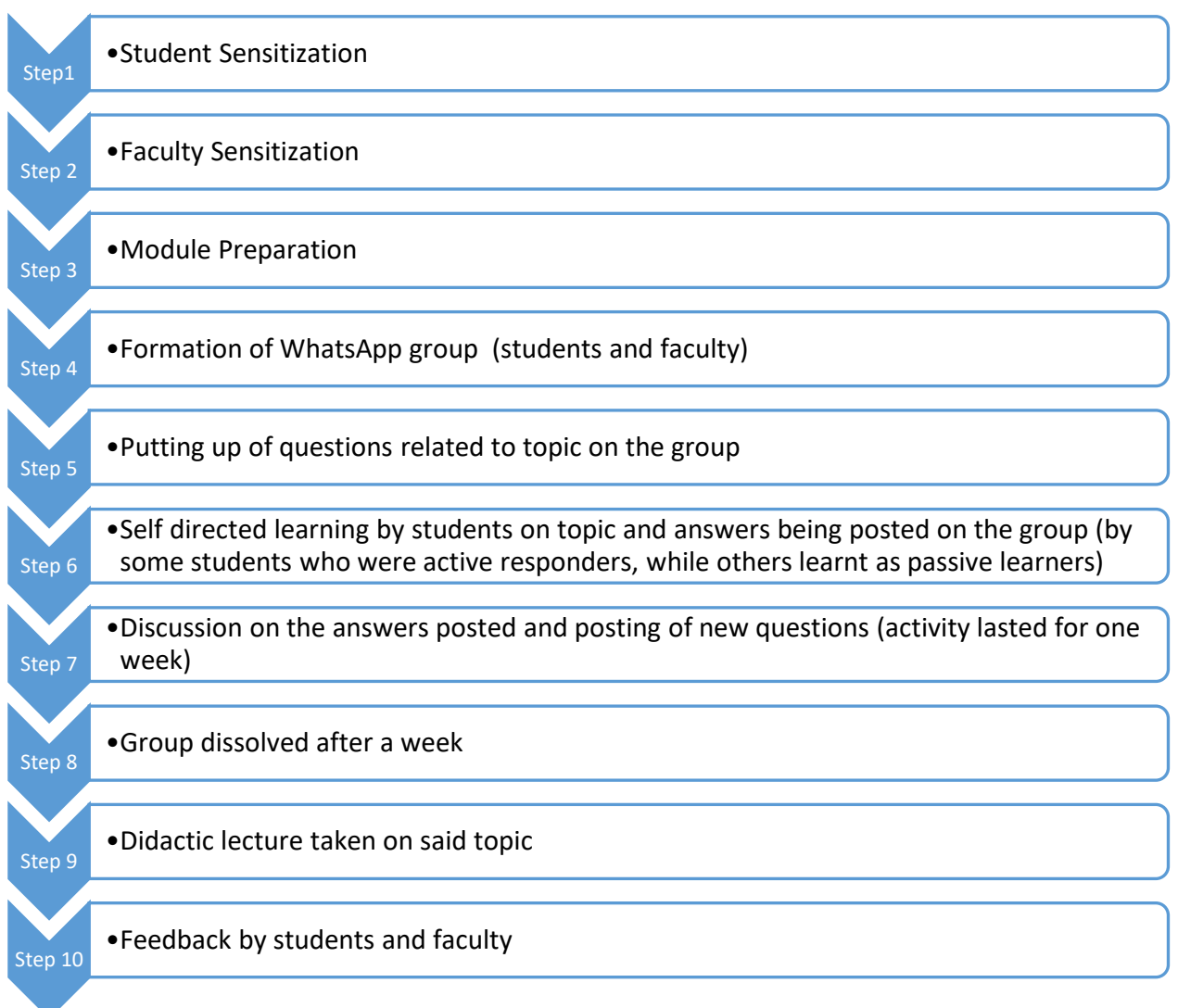

Figure 1: Step wise depiction of methodology used

Student feedback and faculty feedback regarding the attitude and perception towards new method used was taken via pre framed questionnaire using a five-point Likert scale. The questionnaire was duly validated by the residents and faculty peer group. Observations towards the method used was analyzed based on the approach towards the method used, educational impact and practical utility. Qualitative data was generated via open ended descriptive questions and thematic analysis was done.

Faculty: Define Bacteremia and Septicemia.

Student 1: I think bacteremia and septicemia are quite different from each other. Bacteremia is merely presence of bacteria in the blood. Septicemia means that bacteria are using our blood as culture which is dangerous. That's why bacteremia occurs daily but septicemia doesn't.

Faculty: $U$ are right ....., bacteremia is mere presence while in septicemia they are actively multiplying. What are types of bacteremia?

Student 2: Gram positive bacteremia and gram negative bacteremia, if I am not wrong

Figure 2: Extracts from a WhatsApp discussion 


\section{Results}

The group consisted of 94 second professional MBBS students participating with 22 faculty members. Faculty included one Professor and Head, one Professor, one Associate Professor, two Assistant Professors, five Demonstrators and twelve Junior Residents (all are involved in teaching MBBS students either in theory and /or practical classes).
The group was made for one week and a total of 178 messages were exchanged. Out of 94 , $42(44.6 \%)$ students were active responders while $52(55.4 \%)$ were passive participants. Maximum number of messages of 53 were exchanged on day 1 , followed by 30 on day 2 ; 31 on day $3 ; 18$ on day $4 ; 1$ on day $5 ; 26$ on day 6 ; and 19 on day 7 .

Table 1: Student Approach towards WhatsApp and its Advantages as teaching-learning method $(n=94)$

\begin{tabular}{|c|c|c|c|c|c|}
\hline \multicolumn{6}{|c|}{ Approach towards New method: number (\%) } \\
\hline & $\begin{array}{c}\text { Strongly } \\
\text { Disagree } \\
(1)\end{array}$ & $\begin{array}{l}\text { Disagree } \\
(2)\end{array}$ & $\begin{array}{c}\text { Nor Agree } \\
\text { nor disagree } \\
(3)\end{array}$ & $\begin{array}{l}\text { Agree } \\
(4)\end{array}$ & $\begin{array}{c}\text { Strongly } \\
\text { Agree } \\
\text { (5) }\end{array}$ \\
\hline Interesting & $5(5.3)$ & $7(7.4)$ & $13(13.8)$ & $55(58.5)$ & $14(14.8)$ \\
\hline Feasible & $1(1.1)$ & $10(10.6)$ & $24(25.5)$ & $41(43.6)$ & $18(19.1)$ \\
\hline $\begin{array}{l}\text { Can be incorporated into routine } \\
\text { teaching }\end{array}$ & $9(9.57)$ & $11(11.7)$ & $24(25.5)$ & $33(35.1)$ & $17(18.1)$ \\
\hline \multicolumn{6}{|l|}{ Educational Aspects } \\
\hline $\begin{array}{l}\text { Resources/ material given was } \\
\text { sufficient }\end{array}$ & $2(2.1)$ & $8(8.5)$ & 28(29.7) & $43(45.7)$ & 13(13.8) \\
\hline Doubts were cleared effectively & $4(4.2)$ & $10(10.6)$ & 19(20.2) & $45(47.8)$ & $16(17.0)$ \\
\hline $\begin{array}{l}\text { Discussion was more stimulating } \\
\text { and innovative }\end{array}$ & $2(2.1)$ & $8(8.5)$ & $17(18.1)$ & $49(52.1)$ & $18(19.1)$ \\
\hline Better interaction with faculty & $2(2.1)$ & $6(6.4)$ & 13(13.8) & $46(48.9)$ & $27(28.7)$ \\
\hline $\begin{array}{l}\text { Better interaction among peer } \\
\text { group }\end{array}$ & $4(4.2)$ & $14(14.8)$ & $22(23.4)$ & $41(43.6)$ & $13(13.8)$ \\
\hline $\begin{array}{l}\text { Motivation for self-directed } \\
\text { learning }\end{array}$ & $3(3.1)$ & $9(9.6)$ & $22(23.4)$ & $45(47.8)$ & $15(15.9)$ \\
\hline \multicolumn{6}{|l|}{ Practical Utility } \\
\hline Time consuming & $7(7.4)$ & $41(43.6)$ & $21(22.3)$ & $22(23.4)$ & $3(3.1)$ \\
\hline Internet issues & $22(23.4)$ & $38(40.4)$ & $17(18)$ & $13(13.8)$ & $4(4.2)$ \\
\hline
\end{tabular}

Feedback given by students was analyzed and it was found that they had positive approach towards the method used (Table 1). About $14 \%-18 \%$ strongly agreed to its being interesting method of teaching which is feasible to do and can be incorporated in routine teaching. Educational impact was significant and around 40-60\% agreed/strongly agreed that the discussion was stimulating and they were motivated for self-directed learning. They effectively cleared their doubts and benefitted from better student faculty interaction. Practically too, the method can be adopted well as very few admitted to having internet issues (Table 1). Among faculty, there was strong inclination towards the method and there was little doubt regarding its educational impact. However, when compared to students, they were less sure of internet facility (59\%). They were also not clear about the time related issues as most of them were of the view that it can be time consuming (Table 2).

Qualitative data was analyzed and seven main themes were identified (Table 3). 
Table 2: Faculty Approach towards WhatsApp and its Advantages as teaching-learning method $(n=22)$

\begin{tabular}{|c|c|c|c|c|c|}
\hline \multicolumn{6}{|c|}{ Approach towards New method } \\
\hline & $\begin{array}{c}\text { Strongly } \\
\text { Disagree } \\
(\%)\end{array}$ & Disagree (\%) & $\begin{array}{c}\text { Nor Agree } \\
\text { nor disagree } \\
(\%)\end{array}$ & Agree (\%) & $\begin{array}{l}\text { Strongly } \\
\text { Agree (\%) }\end{array}$ \\
\hline Interesting & 0 & $1(4.5)$ & $1(4.5)$ & $14(63.6)$ & $6(27.2)$ \\
\hline Feasible & 0 & $2(9.0)$ & $4(18.1)$ & $11(50.0)$ & $5(22.7)$ \\
\hline $\begin{array}{l}\text { Enthusiasm among students for } \\
\text { the method }\end{array}$ & 0 & 0 & $2(4.5)$ & $15(68.1)$ & $5(18.1)$ \\
\hline \multicolumn{6}{|l|}{ Educational Aspects } \\
\hline $\begin{array}{l}\text { Resources/ material given was } \\
\text { sufficient }\end{array}$ & 0 & $1(4.5)$ & $4(18.1)$ & $17(77.2)$ & 0 \\
\hline Doubts were cleared effectively & 0 & 0 & $5(18.1)$ & $13(59.0)$ & $4(18.1)$ \\
\hline Better interaction with faculty & 0 & $1(4.5)$ & $1(4.5)$ & $13(59.0)$ & $7(31.8)$ \\
\hline $\begin{array}{l}\text { Better interaction among peer } \\
\text { group }\end{array}$ & 0 & $1(4.5)$ & $6(27.2)$ & $11(50.0)$ & $4(18.1)$ \\
\hline \multicolumn{6}{|l|}{ Practical Utility } \\
\hline Time consuming & $1(4.5)$ & $7(31.8)$ & $7(31.8)$ & $7(31.8)$ & 0 \\
\hline Internet issues & 0 & $5(18.1)$ & $13(59.0)$ & $4(18.1)$ & 0 \\
\hline
\end{tabular}

Table 3: Themes identified after analyzing qualitative data generated via open ended questions

\begin{aligned} & \hline Theme 1 Acceptance and inclination for its use \\ & Theme 2 Platform for better interaction with faculty \\ & Theme 3 Realization of learning process \\ & Theme 4 Participation woes \\ & Theme 5 Time related issues \\ & Theme 6 Improvement strategies \\ & Theme 7 Feeling of Bias \\ & \hline\end{aligned}

\section{Discussion}

Internet technology or online technology is changing the way of communication and sharing data. Social networks like Facebook, Twitter, Instagram etc are very popular among the younger generation. One of such application is WhatsApp which was launched by Brian Anton and Jan Koom in 2009 . Its name is derived from the English phrase "What's up?" meaning "What's new?" (Gon \& Rawekar, 2017). It allows exchange of messages (both audio and written) images and videos through the internet. It is a widely used application now a days in social media. Ease of using the application, which is free, along with easy constructing and sharing the information and knowledge makes it a tool which can be used for blended teaching-learning activity between teachers and students.

In our study, maximum enthusiasm among students was seen on day 1 , when maximum number of messages (53) were exchanged. On 
day 4 , the number decreased significantly to only 18 messages while on day 5 , only a single message was shared. The reason was a unit test in Pathology and moreover, it was the weekend. Students were less interested in responding to a teaching activity over weekend and preparation for the test kept them busy. It was difficult for them to give time to other subject taught over WhatsApp.

\section{Acceptability for the method used}

Overall, faculty (90\%) and students (74\%) found the method used was interesting. They also agreed that the method is feasible to implement as routine which shows that students were motivated and faculty was positively oriented towards sharing knowledge online. There was acceptance and inclination to use it as referred by 'brilliant idea', 'another platform for learning' 'fun and stimulating' 'effective and good.' One student said it to be 'better than lecture, topics discussed were of clinical importance' and 'radically different.' Although they also pointed out that 'it lacks structured format and so, can't replace books.'

\section{Educational impact}

About $65 \%$ of students agreed that the resource material shared was sufficient and their doubts were cleared effectively. Around $77 \%$ of faculty was of the same view (Tables $1 \& 2$ ). Previously too, Preston et al., (2010) had reported that nearly $70 \%$ of students in their study stated that they learnt well in online learning communities such as WhatsApp groups, Facebook communities, Twitter chats and Google+ communities.

Thematic analysis revealed that educational impact occurred in the form of 'realization of learning process.' 'New knowledge, new topics and repository for information' or 'the topic was an important one. I even screenshot important facts.' Fifty eight $(62.3 \%)$ students thought that the method prompted them for self-directed learning. One student wrote that it is nice way of learning as you took yourself to internet and learn more.' 'There is better retention.' Passive learning happened and it was mentioned as 'I did not do any message but, I got to know many additional points'.

The interaction among teacher and students was good. About $90 \%$ of faculty felt that interaction was better among student and faculty than routine, but about $76 \%$ of students felt so $(29 \%$ strongly agreed while $47 \%$ agreed). One said 'Learning through WhatsApp was a unique way of discussions among the teachers and the students' Previous studies support the fact that online mobile teaching promotes social interaction between facilitator and students leading to better learning and problem solving (Makoe, 2012; Ashton \& Bhati, 2007). Although $54 \%$ students and $64 \%$ faculty thought that it led to better interaction in peer group, thematic analysis of qualitative data also pointed to 'participation woes.' General observation was that although students were participating, there was lack of much discussion between students, with each other. One student pointed out 'Bias' that 'students were copying things from internet.' This kind of response helps in looking into the psychology of students where they might feel cheated that somebody was quick enough to get his hand on information material available on internet and post it in group when they themselves might still be searching for it in the textbooks to answer. It was mentioned that 'less is left for other students to talk about, once a question is answered, so, you always need to be prompt and quick to answer.'

However, they did enjoy the partial anonymity. Respect and recognition or fear of failure in front of peer group often drives the student's approach to learning and educational activities. One student expressed acceptability to use of this mode of teaching as 'There is no burden of teacher asking you question in the class by your name and making you stand in front of the whole class' Similar observations have been made by Willemse (2015) that students feel less intimidated while asking questions as no one knew their identity.

Parental perception was another aspect as they felt 'Parents do not understand the concept of using mobile for studying.' One student felt no inclination to use WhatsApp in his personal time for study purposes.

\section{Practical Utility}

Since WhatsApp operates through internet, students and faculty were specifically asked about logistics, mainly availability of internet. Students were not at all bothered about internet availability, although faculty was not so sure about it. There are many wireless internet facilities available now a days. One student even mentioned availability of 'Jio'. Internet has led to emergence of online learning communities. There is easy access to multitude of information available and students freely access it. 
There wasn't any consensus or majority regarding whether it is more time consuming or not. Among faculty, majority thought it to be time consuming while among students the verdict was around $50 \%$. Different viewpoints were expressed regarding this. While some felt that 'utilized my free time effectively' others felt 'short messages should be sent as too long message become time consuming' 'sometimes difficult to read all the messages' However, it was realized that time management is must with such activity. Students may have some other assignments and they suggested that either a fixed time slot should be allotted during the day for the activity or such interaction 'should not be held during tests as we are not able to participate and learn at best.'

There were disagreements and few participants were not much inclined towards this method of teaching and expressed it clearly as 'I am not a big fan of studying on mobile phone. Looking on screen for too long is not a thing I want to achieve.' and other one saying 'some people (like myself) do not use WhatsApp on regular basis' 'don't make this routine method of teaching' One of the faculty member also was not at all in favor of it, saying 'I am not much of an advocate of teaching method on phone. I already feel with the availability of simply anything and everything on phone, people are just not ready to look up from their phones. There is no direct interaction and no real expression'.

Our study had limitations as the activity was for a short period of time. The interaction among all faculty members, residents and all students together could have been more, a fact observed by the students and they expressed their wish for more faculty involvement so that they could learn from intellect of all.

Overall, the verdict was in favor that the method is implementable and students often welcome 'something new'. This type of education activity was not used in our set up before. This study might pave a way for utilizing more asynchronous teaching-learning methods in future. However, as a student pointed out that the interest starts waning after first day, the topics/content need to be more image based or clinically oriented to keep the students engaged.

There is no doubt that the concept of use of social media site for teaching-learning process fits well with the learning theory 'Social Constructivism' (Overview of learning theories, Accessed June 9, 2020) Here, knowledge is constructed through connectivism and sharing within social communities. The learner is not learning alone but along with its peer group and in knowledgeable community leading to better contextual understanding.

Thus, we would like to conclude that such activities can be planned with students to introduce new topics, clarify doubts, and increase faculty student interaction. Such groups can also be made interdisciplinary by including faculty from other departments. For example, along with Microbiology, if faculty from department of Pathology, Pharmacology, Community Medicine and General Medicine can also be included to promote discussions on infectious diseases clinical scenarios starting from cause of infection, pathology, their treatment and management, it will be interesting to note the improvement in learning of students via such methods as a significant adjuvant to the routine teaching.

\section{Acknowledgements}

I duly acknowledge the support given by Faculty and Residents of Department of Microbiology, Government Medical College Hospital, Chandigarh. The present work was done as a requisite of Advance Course in Medical Education (ACME).

\section{References}

Alenazi, A.A. (2017) WhatsApp Messenger as a Learning Tool: An Investigation of Pre-service Teachers' Learning without Instructor Presence. Journal of Education and Training Studies, 6, 1, pp. 1-8.

Amry, A.B. (2014) The Impact of WhatsApp Mobile Social Learning on the Achievement and Attitudes of Female Students Compared with Face to Face Learning in the Classroom. European Scientific Journal 10, pp. 116-136.

Ashton, A. \& Bhati, R. (2007) The Use of an Asynchronous Learning Network for Senior House Officers in Emergency Medicine. Emergency Medicine Journal, 24, 6, pp. 427-428.

Barhoumi, C. (2015) The Effectiveness of WhatsApp Mobile Learning Activities Guided by Activity Theory on Students' Knowledge Management. Contemporary Educational Technology, 6, 3, pp. 221-238.

Gon, S. \& Rawekar, A. (2017) Effectivity of ELearning through WhatsApp as a TeachingLearning Tool. MVP Journal of Medical Science, 4,1, pp. $19-25$. 
Kustijono, R. \& Zuhri, F. (2018) January. The Use of Facebook and WhatsApp Application in Learning Process of Physics to Train Students' Critical Thinking Skills. In IOP Conference Series: Materials Science and Engineering Vol. 296, No. 1, pp. 012025. IOP Publishing.

Makoe, M. (2010) Exploring the Use of MXit: a CellPhone Social Network to Facilitate Learning in Distance Education. Open Learning: The Journal of Open, Distance and E-Learning, 25, 3, pp. 251257.

Overview of Learning Theories. https://gsi.berkeley.edu/gsi-guidecontents/learning-theory-research/learningoverview/ [Accessed June 9, 2020].

Preston, G., Phillips, R., Gosper, M., McNeill, M., Woo, K. \& Green, D. (2010) Web-based Lecture Technologies: Highlighting the Changing Nature of Teaching and Learning. Australasian Journal of Educational Technology, 26, 6.
Raiman, L., Antbring, R. \& Mahmood, A. (2017) WhatsApp Messenger as a Tool to Supplement Medical Education for Medical Students on Clinical Attachment. BMC Medical Education, 17, 1, p. 7.

Sener, J. (2010) Why Online Education will Attain Full Scale. Journal of Asynchronous Learning Networks, 14, 4, pp. 3-16.

Willemse, J.J. (2015) Undergraduate Nurses Reflections on Whatsapp Use in Improving Primary Health Care Education. Curationis, 38, 2, pp. 1-7.

Worthington, T. (2013) Synchronizing Asynchronous Learning-Combining Synchronous and Asynchronous Techniques. In 2013 8th International Conference on Computer Science \& Education, pp. 618-621. IEEE. 